oldest Rumanian Version of the New Testament from an MS. in the British Museum. For these services he was awarded the first class of the Rumanian Order of Merit. He was also a Commander of the Rumanian Crown and an honorary member of the Rumanian Academy.

In England Dr. Gaster displayed an active sympathy with the Choveve Zion (Lovers of Zion), a Palestinian Colonization Society. He was president of the English Zionist Federation, and three times vice-president of the International Zionist Congress. He took a part in the initial stage of the negotiations with the British Government which led to the declaration in favour of the establishment of a national home for the Jewish people in Palestine.

In 1890 Dr. Gaster married Lucy, only child of the late Dr. Michael Friedlander, Principal of Jews' College, London. $\mathrm{He}$ is survived by his widow, seven sons, and six daughters. The eldest daughter is the wife of Mr. Neville Laski, K.C.

\title{
Stuart N. Wolfenden
}

The sudden death of Stuart Wolfenden in California on the 28th December, 1938, at the early age of 47 is a sad loss to Oriental studies.

Wolfenden was a charming and agreeable companion, always full of interest and enthusiasm. He was one of those rare but fortunate people who had not only the inclination but also the means and the leisure to pursue research in a field of studies of great scientific importance, but so remote from ordinary scholastic studies that it would not have been regarded as falling within the sphere of any academic appointment.

The subject which he made his own was the comparative philology of the lesser-known Tibeto-Burman dialects and, more broadly, the relationship between Chinese, Tibetan, Burmese, and the other members of the larger group to which they belong. He joined the Society in 1928, and in 1929 his 
Outlines of Tibeto-Burman Linguistic Morphology was published in the Prize Publication Fund Series. Since then he has made a number of other contributions to our Journal and to the publications of other learned societies. His work was always marked by wide research and great care; nor was he merely an arm-chair scholar; he had resided for long periods in the Himalayan regions where the dialects which he was studying are still spoken. It is a tragedy that he was not able to complete, so far as we know at present, the wider and more comprehensive work for which he was obviously preparing himself, but his outlines by themselves entitle him to a permanent place on the roll of honour of the Society.

\section{G. L. K. Clauuson.}

\section{Ella Constance Sykes}

We regret to have to record the death on the 23rd March of Miss Ella Constance Sykes, who held the Secretaryship of this Society during the years 1920-26. Educated at St. Margaret's Hall, Oxford, she turned to the East in 1894, when she joined her brother, Sir Percy Sykes, in Persia, where she accompanied him on many of his tours and wanderings in that historic country and neighbouring lands, including Balūchistān and India, Chinese Turkistān, and the Pāmīrs. Her experiences have been told in graphic and attractive style in her books, Through Persia on a Side Saddle, Persia and its People, and Through Deserts and Oases of Central Asia (in collaboration with her brother). These works reveal chiefly one side of her character, her keen observation of all that surrounded her, whether of historical, artistic or purely human interest, and her broad-minded sympathy with peoples of other faiths and other cultures. Her interest in "things Asian " never flagged, and among her closest friends were men and women distinguished for exploration and wide travel in that continent. 